\title{
Sztancs Edit': A pihenéshez és a szórakozáshoz való jog érvényesülése az elméletben és a (terézvárosi és nyíradonyi) gyakorlatban
}

Debreceni Jogi Műhely, 2011. évi (VIII. évfolyam) 1. szám (2011. január) 33-42.

\section{Bevezető gondolatok}

PhD kutatásaim elsődleges témája a zajvédelem hazai és Európai Uniós szabályrendszerének vizsgálata, melynek során korábban már egy konkrét eset, a „terézvárosi csendrendelet” néven elhíresült szabályozás feldolgozását végeztem el, részben a jogszabályi háttér bemutatásával, részben pedig a kapcsolódó „médiavisszhang” ismertetésével. ${ }^{2}$ A probléma azonban nem csak elvont, a budapestieket érintő kérdés: számtalan helyen nyílt a közelmúltban olyan szórakozóhely (legyen az kerthelyiséggel rendelkező étterem, vagy kifejezetten a fiatalokat megcélzó diszkó), mely a közelben lakók mindennapi nyugalmát kellemetlenül érinti. Ugyanakkor azt sem vitathatjuk el, hogy az érintett vállalkozók (a vállalkozás szabadságából adódóan) bármikor a tetszésüknek megfelelő üzletet nyithatnak - ha be tudják szerezni hozzá a szükséges engedélyeket. Jelen írás keretei között a pihenéshez való jog és a szórakozáshoz való jog összeütközését kívánom megvizsgálni, három aspektusból: egyfelől, mint mond erre vonatkozóan az elmélet és a bírói gyakorlat; másfelől, hogyan nézett ki a két jog viszonya az említett fővárosi kerületi szabályozás esetében - mit gondolt erről a jogalkotó, és milyen elképzeléseik voltak erről a környéken lakóknak vagy éppen a vállalkozóknak. Az írás utolsó részében, miután közvetett módon személyesen is érintett vagyok, hiszen néhány évvel ezelött lakóhelyemen, Nyíradonyban a közelünkben nyílt egy új, teraszrésszel is rendelkező étterem, ezen étterem és a környéken lakók viszonyának bemutatását tűztem ki célomul. Alkalmazott módszerként a tanulmány első részében klasszikus jogi elemzést, második részében a jogi mellett elsősorban a nyomtatott és elektronikus média vonatkozó részében tartalomelemzését, míg harmadik részében kifejezetten saját személyes tapasztalataimon, illetőleg kérdéseimen alapuló benyomások rögzítését végeztem el.

\section{Alapjogok összeütközése}

Az állam elsőrendű kötelessége az alapvető jogok tiszteletben tartása, és védelme, ami nem merül ki abban, hogy az állam tartózkodik megsértésüktől, hanem szervezeti és jogi garanciákkal kell gondoskodnia az érvényesülésükhöz szükséges feltételekről. Azt mondhatjuk tehát, hogy az államnak az alapjogok lehető legkedvezőbb érvényesülését kell biztosítania. ${ }^{3}$ Probléma adódik azonban akkor, amikor az egyes alapvető jogok érvényesítése során a jogok (in concreto) egymással ütköznek.

Ilyen összeütközés figyelhető meg akkor is, pl. amikor a szórakozáshoz való jog gyakorlása a pihenéshez való jogot sérti. Az Alkotmány 70/B § (4) bekezdése ${ }^{4}$ értelmében ugyanis „Mindenkinek joga van a pihenéshez, ${ }^{5}$ szabadidőhöz és a rendszeres fizetett szabadsághoz. Az Alkotmány vonatkozó rendelkezését mind ez ideig még az Alkotmánybíróság sem értelmezte részleteiben, azonban ebből a rendelkezésből vezethető le az éjszakai pihenéshez való jog, éppúgy, mint a szórakozáshoz való jog, ideértve az éjszakai szórakozóhelyeken történő időtöltés jogát is. Ez a rendelkezés továbbá maga után vonja azt a következtetést, mely szerint az alaptörvény csak a pihenés lehetőségét fogalmazza meg alapvető jogként, a szabadidő eltöltésének módját azonban nem alapjogként kezeli, és a korlátozás tekintetében a szociális jogra irányadó szabályok vonatkoznak rá, vagyis számos más alkotmányos jog és alapcél befolyásolja érvényesülését. Kétségtelen, hogy mindkét megközelítés egyaránt fontossággal 
bír, és az egyes személyek igényeitől függ, hogy a kettő közül melyiket tartják fontosabbnak ilyen esetekben pedig a jogalkotónak kell megvizsgálnia, hogy milyen feltételekkel korlátozható ez az alkotmányos alapjog.

Az Alkotmánybíróság állandó gyakorlata szerint egy alkotmányos alapjog korlátozására csak egy másik alapvető jog és szabadság védelme érdekében kerülhet sor, azonban a korlátozás csak akkor alkotmányos, ha ez elkerülhetetlenül szükséges, és ha a korlátozás megfelel az arányosság követelményének, azaz az elérni kívánt cél fontossága és az ezzel okozott érdeksérelem súlya arányban van egymással. Ennek eldöntéséhez azonban az alapjogokat összefüggésükben kell értelmezni, ezért helytelen az a megközelítés, mely egyes alapjogokat megpróbál a rendszerből kiragadva, önállóan kezelni. ${ }^{6}$ Ahogy a Alkotmánybíróság is megállapította 64/1991 (XII. 17.) AB határozatában: „Az emberek természetszerüen egyéni szabadságuk és személyes igényeik szempontjából gyakorolják alapjogaikat. Az államnak viszont arra van szüksége garanciális feladatai ellátásához, hogy az egyes alanyi alapjogok biztositása mellett az azokkal kapcsolatos értékeket és élethelyzeteket önmagukban is, azaz ne csupán az egyes egyedi igényekhez kapcsolódóan védje, s a többi alapjoggal összefüggésben kezelje." Ez a gondolat a konkrét jogok vonatkozásában azt jelenti, hogy a pihenéshez való jog összefügg a testi és lelki egészséghez való joggal ${ }^{7}$ - melynek mintegy garanciája, illetve a mozgásszabadsággal, ${ }^{8}$ mely a szabadidő meghatározott módon való eltöltésének eszközeként jelenik meg. Ennek tükrében úgy vélem azonban, hogy jogunk valójában nem a pihenéshez van, hanem egy olyan környezethez, mely lehetővé teszi a - szintén alkotmányos pihenéshez való jogot. ${ }^{9}$ A fent idézett alkotmánybírósági rendelkezés a pihenéshez való jog tekintetében azt jelenti, hogy nem értelmezhető úgy az Alkotmány, hogy az ország egész területén mindenki ott, úgy és akkor gyakorolhatja a pihenéshez való jogát, ahol és ahogyan tetszik $^{10}$. Ugyancsak a fentiekből következő módon sem az éjszakai pihenéshez, sem pedig az éjszakai szórakozáshoz való jogot nem lehet kizárólagosnak tekinteni, hanem meg kell határozni a két aspektus egymáshoz való viszonyának ésszerủ arányát.

\section{Hatályos jogszabályok és önkormányzati mozgástér}

Ahogyan arra már korábban is utaltam, az Alkotmány biztosítja a pihenéshez való jogot, nincs azonban olyan rendelkezése, amely meghatározná a pihenés és szórakozás módját, feltételeit. ${ }^{11}$ Számos olyan jogszabályi elö́rás létezik ugyanakkor, mely különböző korlátozásokat, tilalmakat fogalmaz meg annak érdekében, hogy a pihenéshez való jog és annak egyes aspektusai a jogrendszer más szabályaival való lehető legteljesebb harmóniában érvényesüljenek. ${ }^{12} \mathrm{Az}$ alkotmánybírósági alkotmányértelmezésből, és a pihenéshez való jog funkciójából az következik, hogy az alaptörvény a pihenéshez való jogot fogalmazza meg alapvető jogként, ${ }^{13}$ és annak részaspektusait törvényi szintnél alacsonyabb jogforrás rendezi. A nem törvényi szinten meghatározott korlátozásoknak az indoka egyrészt a fennálló helyzet alaposabb ismerete, másrészt pedig az, hogy ezek sosem kifejezetten a pihenéshez való jogot korlátozzák, hanem a pihenést csak áttételesen érintik, vagyis ebben az esetben is irányadó az a szabály, hogy az alapjog részaspektusait törvényi szintnél alacsonyabb jogforrás rendezi. E szabályozásnak azonban - a jogállamiság elvének megfelelően - törvényen kell alapulnia. ${ }^{14}$

Amint arra utaltam, számos olyan jogszabály létezik, amely közvetlenül vagy közvetett módon meghatározza a pihenés és szórakozás módját és feltételeit. Így, pl. a kereskedelemről szóló törvény ${ }^{15}$ értelmében az üzletek nyitvatartási idejét a vásárlási szokások, a foglalkoztatottak és a lakókörnyezet érdekeinek figyelembe vételével a kereskedő állapítja meg. A törvény ugyanakkor felhatalmazást $\mathrm{ad}^{16}$ az önkormányzatoknak arra, hogy a helyi 
sajátosságok figyelembe vételével az üzletek éjszakai (22 és 6 óra közötti) nyitva tartását rendeletben szabályozzák. Mindez azt jelenti, hogy föszabály szerint tehát a kereskedő határozza meg a nyitvatartási időt, azonban amennyiben az önkormányzat él a törvényben foglalt rendeletalkotási jogosultságával, azt a kereskedő köteles betartani. Az Alkotmánybíróság a 282/B/2007. AB határozatában ${ }^{17}$ úgy vélte, hogy , Mindezzel az Országgyülés, mint jogalkotó azt juttatta kifejezésre, hogy megfelelöbbnek tartja, ha az üzletek éjszakai nyitva tartásának szabályozása tekintetében teret kap a helyi közösségek adott esetben eltérö - igényeit figyelembe vevö önkormányzati rendeletalkotás", éppen ezért nem minősítette alkotmányellenesnek a fenti rendelkezést. Ugyanakkor az önkormányzat ,, $a z$ éjszakai nyitva tartást általános jelleggel szabályozhatja. Ettöl eltéröen egy adott, konkrét vendéglátó-ipari egység nyitva tartásának a korlátozása nem jogalkotói, hanem hatósági hatáskörbe tartozik (Ker. tv. 6. § (5)-(6) bekezdés), amely döntés ellen a közigazgatási hatósági eljárás és szolgáltatás általános szabályairól szóló 2004. évi CXL. törvény alapján jogorvoslatnak van helye."

Arra vonatkozóan, hogy mit kell érteni a helyi sajátosságok figyelembe vételén, sem a kereskedelmi törvény, sem pedig más jogszabály nem ad magyarázatot, azonban általában elvárható, hogy előzetes hatásvizsgálat lefolytatására kerüljön sor annak megállapítására, hogy a korlátozás nélküli helyzet ténylegesen mennyiben zavarja a lakosság nyugalmát.

Általános követelményként elmondható, hogy az éjszakai nyitva tartás szabályozása során tekintettel kell lenni az Alkotmányban ${ }^{18}$ foglalt hátrányos megkülönböztetés tilalmára is, azaz az önkormányzat helyi szabályozása, amennyiben az nem valamennyi szórakozóhelyre vonatkozik, csak akkor tekinthető alkotmányosnak, ha objektív ismérvek alapján tesz különbséget egyes szórakozóhelyek között. ${ }^{19}$ Meglátásom szerint elfogadható, ha az önkormányzat a település egyes utcáira, övezeteire vonatkozóan állapít meg tilalmat, hiszen ez tekinthető objektív ismérvnek, különösen, ha a kivételek között mondjuk a turisták által gyakran látogatott, idegenforgalmi szempontból frekventált övezetek is megtalálhatóak. Úgyszintén elfogadható kivétel lehet az éjszakai nyitva tartás hétvégékre (péntek, szombat esték) korlátozása is. Ugyanakkor, miután nehezen képzelhető el, hogy egy település egészén ugyanazok a helyi sajátosságok állnának fenn a hét minden napján annak ellenére, hogy a törvény általában (kivételektől eltekintve) megengedi föszabály szerint az éjszakai nyitva tartást, ezért álláspontom szerint általában kijelenthető, hogy egy egész településre vonatkozó állandó éjszakai nyitva tartási tilalom kimondása nagy valószínüséggel alkotmányellenes szabályozási helyzetet eredményezne.

Az üzletek müködéséről és a belkereskedelmi tevékenység folytatásáról szóló 4/1997. Kormányrendelet értelmében ,vendéglátó üzletben a vendégek szórakoztatására müsoros elöadás, zene, tánc rendezhetö", ${ }^{20}$ amit be kell jelenteni a jegyzőnek és a területileg illetékes rendőrhatóságnak. A jegyző megtilthatja a zene szolgáltatását, ha az jogszabálysértő (pl. nem jelentették be), vagy az a közízlést, esetleg a lakosság érdekeit és nyugalmát (pl. pihenéshez való jogát) sérti, mely tiltás azonnal végrehajtható. A jegyző zajterhelés esetén, ha ez meghaladja a jogszabályban ${ }^{21}$ meghatározott zajterhelési határértéket, 22 és 6 óra között korlátozhatja az üzlet nyitva tartását, illetőleg kötelező zárva tartási időt rendelhet el, valamint bírságolhat is.

Ugyancsak szabályozási lehetőséget biztosít az önkormányzatok számára az 1991. évi XX. évi törvény, ${ }^{22}$ valamint az 1995 . évi LIII. törvény. ${ }^{23} \mathrm{Ez}$ utóbbi jogszabály értelmében ${ }^{24}$ a települési önkormányzat a környezetvédelmi feladatok megoldására önkormányzati rendeletet 
bocsát ki, illetőleg határozatot hoz, míg a települési önkormányzat képviselő-testülete önkormányzati rendeletben a más jogszabályokban elöírtaknál nagyobb mértékben korlátozó környezetvédelmi előírásokat határozhat meg. ${ }^{25} \mathrm{~A} \mathrm{Htv}{ }^{26}$ rendelkezései alapján a képviselőtestület feladat- és hatáskörébe tartozik a helyi zaj- és rezgésvédelmi szabályok megállapítása, melybe álláspontom szerint beletartozhat a csendhez és pihenéshez való jog biztosításának lehetősége is adott esetben.

\section{A terézvárosi csendrendelet az álláspontok tükrében}

A médiában elhíresült, és a budapesti lakosok körében nagy port kavart Budapesti Főváros VI. kerület Terézváros Önkormányzat képviselő-testületének 20/2009. (VI. 29.) számú, ${ }^{27}$ 2009. szeptember 1. napjától hatályban lévő rendelete a fenti jogszabályi keretek között született, és deklarált célja a terézvárosi lakók nyugalmának biztosítása érdekében az önkormányzat illetékességi területén lévő szórakozóhelyek éjszakai nyitva tartásának ${ }^{28}$ szabályozása volt. A rendelet értelmében ${ }^{29}$ az üzletek ${ }^{30} 22$ óra és másnap reggel 6 óra között nem tarthatnak nyitva, kivéve egyrészt szilveszter éjszakáját, másrészt pedig, ha az üzlettel egy épületben levő lakók legalább kétharmada ehhez hozzájárul, vendéglátó üzleteknél legfeljebb hajnali egy óráig, teraszok esetében legfeljebb éjfélig, kereskedelmi üzleteknél reggel 6 óráig (ez utóbbiaknál azonban 22 óra és 6 óra között nem forgalmazható alkohol ettől függetlenül sem). ${ }^{31}$ Nem kocsmázhatnak tehát a Kuplungban, a Kiadóban, vagy a Liszt Ferenc téren, a „20-as évek Amerikájának” hangulata érződik a Terézvárosban - olvashattuk a napi sajtóban. ${ }^{32}$

Takács Albert korábbi igazságügyi és rendészeti miniszter a rendelethez kapcsolódó szakmai állásfoglalásában úgy ítélte meg, nem tekinthető a „helyi sajátosságok figyelembe vételének”, ha egy önkormányzat nincs tekintettel a szabályozása során arra, hogy egy területen szórakozó negyed jött létre, és itt egyáltalán nem engedélyezi a vendéglátó és szórakozó helyek éjszakai nyitva tartását. Takács további problémának látta, hogy a rendelet szerinti „lakó” definíciója nem alkalmas a kívánt szabályozási cél elérésére, hiszen egy sürün lakott, ráadásul üzletekkel is sürün ellátott területrészen egy üzlet müködése nem csupán annak a háznak a lakóit zavarhatja, amelyben a szórakozóhely található, hanem a szomszédos vagy éppen szemben levő épület lakóit is. Takács Albert aggályosnak tartja végezetül, hogy a rendelet szerint a tulajdonos családtagjai nem minősülnek lakónak, illetőleg a tulajdonosnak (szemben például a társasházakról szóló 2003. évi CXXXIII. törvénnyel) csak utolsó sorban, az ingatlan használóját követően van lehetősége fellépni a szórakozóhellyel szemben.

A rendelet megalkotását Kékesi Tibor helyi és országgyülési képviselő (MSZP) terjesztette elő, mely kezdeményezés hátterében a vendéglátóhelyekről kiszűrődő zajra, utcai hangoskodásra, gépjárművek megrongálására és a koszos kapualjakra érkező lakossági panaszok álltak. „, A kerületben élők által tett bejelentések, amelyek a közterület rendjének és a közbiztonságnak a megzavarásáról szólnak, mára verték $k i$ a biztositékot az önkormányzatnál olyan mértékben, hogy lépjünk, $s$ szigoritsuk a vendéglátóhelyek müködését." - mondta el Kékesi Tibor a hvg.hu-nak adott interjújában. ${ }^{33}$

A rendelet létrejöttének körülményeivel összefüggésben fontos megemlíteni azt, hogy a képviselő-testületben egy képviselő tartózkodott, s csupán egy képviselő ellenezte azt, mondván, hogy jobbnak tartaná a szankciók és eljárások szigorítását. A többiek egyetértettek abban, hogy a turisztikai szempontok figyelembe vételével is fontosabb a terézvárosiak pihenéshez való igényének szem előtt tartása. ${ }^{34}$ A teljesség kedvéért szeretném megjegyezni, 
hogy tizenegy budapesti kerület képviselö-testülete nem élt a felhatalmazás lehetőségével, a VI. kerület vezetése azonban drákói szigorral csapott le Budapest legtöbb vendéglátóhellyel rendelkező városrészére.

A rendelettel szemben nem csak a főváros ${ }^{35}$ fejezete ki tiltakozását,, de a kereskedelmi kamarák is aggályosnak tartották a szabályozást. A fővárosiak arra hivatkoztak, hogy a rendelet ellehetetleníti az idegenforgalmi szempontból kiemelkedő jelentőségü, VI. kerületi Broadway-t is ${ }^{36}$. A takarodo.com civil kezdeményezés keretében emeltek szót a rendelet ellen, majd Koccintás néven csendes tüntetést végeztek, s végül a Facebook nevü internetes oldalon szerveztek szavazást abból a célból, hogy vonják vissza a rendeletet. Az Újkorcsoport ${ }^{37}$ nevet viselő civil kezdeményezők társasága is ellenezte a rendeletet, mondván, hogy az szükségtelenül és aránytalanul korlátozza a kulturáltan szórakozni vágyók jogát. Álláspontjuk szerint a nyugalomhoz való jog mellett létezik a kulturált szórakozáshoz való jog is, azonban a rendelet a kulturált szórakozáshoz való jog rovására aránytalan védelemben részesíti a helyiek nyugodt lakókörnyezetben való jogának gyakorlását. ${ }^{38}$ Véleményük szerint az önkormányzat döntése nem számol a rendelet társadalmi, kulturális, nemzetgazdasági és turisztikai hatásaival.

A Liszt Ferenc téri, Andrássy úti, Hajós utcai, Nagymező utcai vendéglátósokat tömörítő Broadway Egyesület is fellázadt a rendelet ellen, annak alkotmánysértő, diszkriminatív, önkényes és alkalmazhatatlan voltára hivatkoztak. Véleményük szerint a rendelet alkalmazásával ugyanis kiürül a főváros belvárosának hagyományos szórakozónegyede. A kerületek üzleteinek értéke drasztikusan csökkenne, ami munkahelyek ezreinek megszünését vonná maga után. Az önkormányzat, valamint a lakók is jelentős bevételtől esnének el, és alapvetően megváltozna a világörökség részévé nyilvánított Andrássy-út arculata. ${ }^{39}$

A Budapesti Kereskedelmi és Iparkamara is aggályosnak találta a szabályozást, hisz az önkormányzat rendelete a vendéglátóhelyek részére kiadott müködési engedélyeket semmisítené meg. Egyetértek Illés Zoltán fideszes politikussal, ${ }^{40}$ aki szerint a nyitva tartás korlátozása túl komoly szankció, hisz a tudomány jelenlegi keretei között megoldható - és az kívánt cél elérése szempontjából eredményre vezető - lenne az, ha a vendéglátóhelyek zajcsökkentő és zajszigetelő technikával próbálnák elérni a környéken élők nyugalmának biztosítását. Ily módon az is kivédhető lenne, hogy az önkormányzat több százmilliós adóbevételtől elessen.

A Kamara meglátása alapján az érintettekkel való egyeztetés nélkül, egyes civil szervezetek rosszul értelmezett lobbijának hatására, példa nélküli nyitvatartási rendet fogadott el a képviselö-testület. ${ }^{41}$ Szerintük a rendelet szerzett jogokat vesz el az üzletek tulajdonosaitól, ami a kamara szerint súlyosan alkotmányellenes. Az Alkotmány támogatja és elismeri a vállalkozáshoz való jogot, és a gazdasági verseny szabadságát, a kerületi önkormányzati rendelet viszont épp ezt korlátozza. ${ }^{42} \mathrm{Az}$ érdekképviseleti szerv álláspontja szerint a gazdasági verseny szabályai is sérülnek azáltal, hogy Budapest egyéb kerületeiben egyáltalán nincs korlátozó szabályozás, vagy ha van is, az sokkal méltányosabb, ezért a más kereskedelmi vendéglátóhelyek forgalma a Terézvárosban müködő üzletek rovására nőni fog. Ezáltal a vállalkozáshoz való jog sérülhet. Az Alkotmánybíróság ezzel kapcsolatban azonban egy korábbi ügyben a következő megállapításokat tette ${ }^{43}$ : „A vállalkozás joga a foglalkozás szabad megválasztásához való alkotmányos alapjog ${ }^{44}$ egyik aspektusa. A vállalkozás joga azt jelenti, hogy bárkinek Alkotmány biztositotta joga a vállalkozás, azaz üzleti tevékenység kifejtése. A vállalkozás joga tehát nem abszolutizálható, és nem korlátozhatatlan: senkinek 
sincs alanyi joga meghatározott foglalkozással kapcsolatos vállalkozás, sem pedig ennek adott vállalkozási jogi formában való gyakorlásához. A vállalkozás joga annyit jelent - de annyit alkotmányos követelményként feltétlenül -, hogy az állam ne akadályozza meg, ne tegye lehetetlenné a vállalkozóvá válást. Az éjszakai nyitva tartás korlátozása nem teszi lehetetlenné a vállalkozáshoz való jog gyakorlását." Véleményem szerint nem jelent diszkriminációt az, hogy a terézvárosi rendelet miatt az egyéb kerületekben lévő üzletek forgalma esetlegesen nő, hisz az egyes önkormányzatok szabályozása jogszerü akkor, ha összhangban van a törvényekkel, még akkor is, ha a szabályozás az egyes kerületekben eltérő. Más kérdés, hogy abszurd helyzet alakul ki, ha egy utca két oldalán eltérő szabályok érvényesülnek.

A kiéleződött helyzet azt vonta maga után, hogy a Budapesti Kereskedelmi és Iparkamara az Alkotmánybírósághoz fordult. Az Alkotmánybírság azonban nem hozott határozatot az ügyben, ráadásul a tiltakozás nyomán az önkormányzat is meghátrált, és egy olyan kompromisszumot kötött a vendéglátósokkal, hogy átdolgozzák a rendeletet a vállalkozások javaslatai alapján. A rendelet módosításáról szóló 30/2009. (X. 26.) rendelet értelmében az üzlettel egy épületben lakók (lakásonként egy nyilatkozattal), ennek hiányában a tulajdonosok (tulajdoni hányaduk arányában) több mint felének írásos hozzájárulásával reggel 6 óráig tarthatnak nyitva a vendéglátó üzletek, a teraszok nyitva tartására vonatkozó szabályok változatlan fenntartása mellett. Ezzel párhuzamosan az önkormányzat támogatásával a VI. kerületi Vendéglátóipari és Élelmiszerkereskedelmi Üzletek Érdekvédelmi Egyesülete elindította a Csendet kérünk! kampányt a kulturált szórakozás jegyében. A kampány lényege, hogy sikerüljön egy, mind a lakók (pihenéshez való jogát), mind a szórakozni vágyók igényeit egyaránt kielégítő viselkedéskultúrát kialakítani az önkormányzat területén levő szórakozóhelyeken.

\section{Ugyanaz a probléma - máshol}

Szűkebb lakóhelyemen, egészen pontosan a lakásunkkal szemben 2007-ben nyílt meg a Vénszarvas vendéglő, melynek mindennapi müködése során ugyancsak felmerül sajnos a tulajdonos és a szórakozni vágyó vendégek, valamint a pihenésre vágyó, közelben lakók jogainak ütközése. A Vénszarvas vendéglő a nyolcezer fös (Aradványpusztával és Tamásipusztával együtt 12 ezer fös) Nyíradony három éttermének egyike, fekvése alapján (a fötérhez, közlekedési lehetőségekhez való közelségére tekintettel) a közvélekedés szerint a három közül a második legjobb helyen található. A vendéglö kerthelyiséggel is rendelkezik, mely komoly zajszennyezés forrása esetenként, különösen hétvégeken és egyes zártkörü rendezvények (ballagás, esküvő, születésnapi ünnepségek és hasonlók) alkalmával. A vendéglő hivatalos nyitvatartása teljes mértékben megfelel mind a nyíradonyi kereskedelmi üzletekkel szemben támasztott elvárásoknak, mind pedig a környéken lakók elvárásainak (1022 óra között tart nyitva), ám az elmélet és a gyakorlat sajnos ebben az esetben is elválik egymástól: részben az éttermek közötti versenyhelyzet miatt, részben pedig a tulajdonos anyagi érdekeltsége miatt a föszezon idején a tényleges záróra csak nagyon ritkán van valóban 22 órakor, ami különösen a nyári időszakban rendkívül zavaró a környéken lakók számára. A nyíradonyi önkormányzat (figyelemmel mindenekelött a térségben tapasztalható nagy munkanélküliségre, illetőleg az önkormányzati bevételek szükösségére) az elmúlt években semmilyen, a különféle szórakozóhelyek müködését korlátozó rendeletet nem hozott, és legjobb tudomásom szerint ilyenek meghozatalát nem is tervezi.

A Vénszarvas vendéglő elhelyezkedése rendkívül sajátos, ami jól mutatja egyben a hazai jogi szabályozás elégtelenségét is: bár az étteremmel szemben három ház (köztük a mienk is) 
található, az étterem fizikai címe és bejárata hivatalosan egy másik keresztutcában van, aholis a tulajdonosnak mindössze egy nyugdíjas házaspár beleegyezését kellett megszereznie a használatbavételi engedély igényléséhez, a zajszennyezés tényleges elviselöit nem. Ezt (az idős emberek befolyásolhatóságán túl) már csak azért is könnyedén meg tudta tenni a tulajdonos, mert az említett kerthelyiséggel a nyugdíjas házaspár lakása nem érintkezik.

Valamennyi, a környéken lakó érintett megkérdezésével készítettem egy áttekintő véleményt az étterem müködéséről, a tapasztalatokat az alábbi táblázat részletezi:

\begin{tabular}{|c|c|c|c|}
\hline Életkor (nem) & $\begin{array}{l}\text { Szokott-e az } \\
\text { étterembe járni }\end{array}$ & $\begin{array}{c}\text { Jelent-e problémát } \\
\text { számára az étterem } \\
\text { müködése }\end{array}$ & $\begin{array}{c}\text { Tett-e bármilyen } \\
\text { lépést az } \\
\text { étteremmel } \\
\text { szemben }\end{array}$ \\
\hline 17 (nö) & nem & igen, alkalmanként & ő nem, a szülei igen \\
\hline 22 (férfi) & rendszeresen & nem (,bulizós”) & nem \\
\hline 24 (nő) & ritkán & igen, alkalmanként & $\begin{array}{ll}\text { jelezte } & \text { a } \\
\text { tulajdonosnak }\end{array}$ \\
\hline 27 (nö) & nem & $\begin{array}{l}\text { nem (nem szokott } \\
\text { otthon lenni) }\end{array}$ & nem \\
\hline 41 (férfi) & nem & $\begin{array}{l}\text { nem (munkája miatt } \\
\text { nincs otthon } \\
\text { esténként) }\end{array}$ & nem \\
\hline 46 (nő) & ritkán & $\begin{array}{l}\text { nem (a szobájuk nem } \\
\text { utcafronti) }\end{array}$ & nem \\
\hline 49 (férfi) & nem & $\begin{array}{l}\text { nem (a szobájuk nem } \\
\text { utcafronti) }\end{array}$ & nem \\
\hline 50 (nö) & nem & igen, alkalmanként & nem \\
\hline 54 (nö) & ritkán & $\begin{array}{l}\text { igen (elsősorban a } \\
\text { gyermekük miatt, a } \\
\text { vendégek } \\
\text { viselkedése) }\end{array}$ & $\begin{array}{l}\text { jelezte a } \\
\text { tulajdonosnak, } \\
\text { hatósági bejelentést } \\
\text { helyezett kilátásba }\end{array}$ \\
\hline 56 (férfi) & nem & $\begin{array}{l}\text { igen, fóleg nyári } \\
\text { hétvégéken (nem tud } \\
\text { aludni) }\end{array}$ & $\begin{array}{ll}\text { jelezte } & \text { a } \\
\text { tulajdonosnak }\end{array}$ \\
\hline 64 (nö) & nem & $\begin{array}{l}\text { igen, rendszeresen } \\
\text { (nem tud aludni) }\end{array}$ & $\begin{array}{l}\text { jelezte a } \\
\text { tulajdonosnak, } \\
\text { hatósági bejelentést } \\
\text { helyezett kilátásba }\end{array}$ \\
\hline 65 (nő) & nem & $\begin{array}{l}\text { nem (csak jogilag } \\
\text { szomszéd, fizikailag } \\
\text { nem) }\end{array}$ & nem \\
\hline 70 (férfi) & nem & $\begin{array}{l}\text { nem (csak jogilag } \\
\text { szomszéd, fizikailag } \\
\text { nem) }\end{array}$ & nem \\
\hline 74 (férfi) & nem & $\begin{array}{l}\text { igen, rendszeresen } \\
\text { (nem tud aludni) }\end{array}$ & $\begin{array}{l}\text { jelezte a } \\
\text { tulajdonosnak, } \\
\text { hatósági bejelentést } \\
\text { helyezett kilátásba }\end{array}$ \\
\hline
\end{tabular}


Az adatokat kiértékelve megállapítható, hogy az étteremnek a fó célközönsége a szomszédok közül is (miként általában is Nyíradonyban) a fiatalabb generáció, mely azonban néhány esetben a még elfogadható határon túli alkoholfogyasztásban, és ezzel összefüggő viselkedési problémákban ölt testet. Általában a fiatalabb generáció ugyanakkor toleránsabb is ezzel a viselkedéssel szemben, feltehetően azért, mert néhány esetben maga is hajlamos a szórakozás ezen formáját választani. A középkorú és az idősebb generációs esetében egyértelműen kijelenthető, hogy akiknek a lakása vagy szobája közvetlenül érintkezik az étterem kerthelyiségével, legalább alkalmanként problémákat tapasztal a túl hosszú ideig tartó nyitva tartás és a vendégek viselkedése miatt, ugyanakkor (miként azt a Polgármesteri Hivatalban kérdésemre meg is erősítették) egyetlen hivatalos bejelentés sem érkezett az étteremmel szemben müködésének immáron lassan négy esztendeje alatt. Hasonló tapasztalatokról számolt be a nyíradonyi rendőrség munkatársa is, megjegyezve azonban, hogy az étteremböl távozókkal szemben több alkalommal került már sor rendőri intézkedésre (elsősorban igazoltatásra, illetőleg a csendesebb hazatérésre való figyelmeztetésre, de egy esetben garázdaság miatt előállításra is sor került már).

Összevetve ezeket a tapasztalatokat a terézvárosi ügyben elhangzott érvekkel, a magam részéről (részben úgyis, mint érintett) egyet tudok érteni a terézvárosi önkormányzat eredeti döntésével, hiszen ha egy alig tízezer fös, nem központi fekvésű városban az érintettek fele (14-ből 7 fö) úgy nyilatkozott, hogy legalább alkalmanként zavarja őt az étterem éjszakai müködése, akkor könnyen elképzelhetjük, mit jelent egy teraszos vendéglátóhely múködése egy olyan turisták által gyakran látogatott, Budapest építészeti sajátosságai miatt a hangot megfogó, visszhangzó területen, mint a Terézváros vonatkozó része. Ugyanakkor, a nyíradonyi tapasztalatok alapján állítható, hogy a környéken lakók nem elsősorban az éjszakai nyitvatartást, hanem az éjszakai nyitva tartás során felszolgált alkohol hatására az átlagosnál hangosabb zajszintet kifogásolják - azaz valószínüleg semmilyen problémájuk nem lenne egy akár hajnalig tartó nyitvatartással sem, amennyiben ez nem jár együtt a vendégek mulatozásával. Ugyanezt a kérdést megvizsgálva más oldalról is, azonban már kicsit árnyaltabb képet kapunk: egyfelől a tulajdonos számára a fő hasznot az alkoholárulás jelenti szerte a világon, és ennek hiányában nincs igazán értelme az éjszakai nyitvatartásnak viszonylag kevés olyan szórakozni vágyó fiatal van ma Magyarországon vagy világszerte, aki éjfélkor nem még egy sörre, hanem mondjuk egy szarvasragura vágyik. Másfelöl, az érintett vendégkör számára a szórakozáshoz való jog fontos részét képezi, hogy éjszaka is bármikor tudnak számukra megfelelő szórakozási lehetőségek közül választani - és azt kell mondanom, a „talponálló” jellegű szórakozóhelyekhez képest (melyek a lakóhelyemtől távolabb esnek) a Vénszarvas vendéglő sokkal kulturáltabb lehetőségeket nyújt.

\section{Következtetés}

Az imént bemutatott önkormányzati rendelet, illetve az ahhoz kapcsolódó vélemények példaként szolgáltak arra, hogy egy alkotmányos alapjog adott esetben nem gyakorolható a másik sérelme nélkül. Ilyenkor a jogalkotónak kell eldöntenie azt, hogy melyik jogot korlátozza a másik rovására. Ennek megítélése nem könnyü feladat, hiszen mindenképpen valamilyen kompromisszum jelentheti csak a megoldást. Ilyen köztes megoldás kialakítása volt célravezető a terézvárosi rendelet esetében is. A kompromisszumos megoldás eredményeképpen ugyanis sikerült biztosítani a fővárosi lakosságnak a kulturált szórakozáshoz való jogot, anélkül, hogy a lakók pihenéshez való joga csorbulna. Ez a megoldás véleményem szerint alkotmányos, $\mathrm{s}$ a jogalkotók az elérni kívánt célt biztosították vele. Kisebb közösségekben azonban nem feltétlenül szükséges a jogalkotó beavatkozása 
sem: szerencsés esetben a tulajdonos üzleti érdekeinek veszélyeztetése nélkül is elérhető olyan kompromisszum, amely mind a tulajdonos, mind a szórakozni vágyó vendégek, mind pedig a pihenni szándékozó helyben lakók számára elfogadható kompromisszumos megoldást jelent.

${ }^{1} \mathrm{PhD}$ hallgató, DE-ÁJK

${ }^{2}$ Sztancs Edit: A pihenéshez és a szórakozáshoz való jog érvényesülése a terézvárosi csendrendelet tükrében. (Debrecen, 2010, megjelenés alatt)

${ }^{3}$ Bárándy Péter K/746/1. számú javaslata Pap János országgyülési képviselőnek - 2007. augusztus 27.

${ }^{4}$ Alkotmány $70 / \mathrm{B} \S(4)$ bekezdés

${ }^{5}$ A pihenéshez való jog az alapjogok második generációjába tartozó, szociális alapjog.

${ }^{6}$ Ennek beszédes példája az országos sajtóban is napvilágot látott „, harangzúzás-eset” (Kfv.II.39.166/2007/8), ahol az újonnan épített templomból magnóról szóló harang hangjának ereje igencsak zavarta a templomot körülvevő, korábban épült házak lakóit. Az ügy két jogorvoslati lépcsőfok után a Legfelsőbb Bíróság elött fejezödött be, amely szerv döntésével a lelkiismereti és vallásszabadságra - mint Alkotmányban rögzített alapjogra hivatkozással - mindenfajta korlátozásoktól mentes harangozást engedélyezett, figyelmen kívül hagyva azonban a szintén Alkotmány által deklarált tulajdonhoz való jogot, illetve egészséges környezethez való jogot.

A bíróság minimális feladata pedig épp a három alapjog egymáshoz való viszonyának feltárása lett volna.

${ }^{7}$ Alkotmány 70/D. §

8 Alkotmány 58. §

${ }^{9}$ www. lehetmas/index.hu - 2010. május 1-jei letöltés

${ }^{10}$ Chronowski Nóra- Drinóczi Tímea- Petrétei József- Tilk Péter- Zeller Judit: Magyar alkotmányjog III., Alapvetô Jogok, Dialóg Campus Kiadó, 2006, 521. o.

${ }^{11} 1005 / \mathrm{B} / 1996 \mathrm{AB}$ határozat

${ }^{12}$ Bárándy Péter K/746/1. számú javaslata Pap János országgyülési képviselő Úrnak - 2007. augusztus 27.

13 1403/B/1991 AB határozat, 1992. 493., 494. ABH, 1005/B/1996 AB határozat, 1030/B/2004 AB határozat

${ }^{14}$ Chronowski Nóra- Drinóczi Tímea- Petrétei József- Tilk Péter- Zeller Judit: Magyar alkotmányjog III., Alapvető Jogok, Dialóg Campus Kiadó, 2006, 521. o.

${ }^{15}$ 2005. évi CLXIV. törvény $6 . \S$

${ }^{16}$ 2005. évi CLXIV. törvény 6. § (4) bekezdés

${ }^{17} 282 / \mathrm{B} / 2007 \mathrm{AB}$ határozat

${ }^{18}$ Alkotmány 70/A. $§(1)$ bekezdése

${ }^{19}$ 55/1998. (XI. 27.) vagy a 61/1992. (X. 20.) AB határozatot

${ }^{20} 4 / 1997$ (I.22.) Kormányrendelet 17.§ (1) bekezdés

21 (8/2002. (III. 22.) KöM-EüM együttes rendelet)

22 1991. évi XX. törvény (Htv.) a helyi önkormányzatok és szerveik, a köztársasági megbízottak, valamint egyes centrális alárendeltségü szervek feladat- és hatásköreiről szóló törvény

${ }^{23} 1995$. évi LIII. törvény a környezet védelmének általános szabályairól

${ }^{24}$ Kvtv. 46. § (1) bekezdés c, pontja

${ }^{25}$ Kvtv. 48. § (1) bekezdés

${ }^{26}$ Htv. 85. § (1) bekezdés e, pontja

${ }^{27}$ Budapest Főváros VI. kerület Terézváros Önkormányzat Képviselő - Testületének 20/2009 (VI. 29.) rendelete az üzletek éjszakai nyitvatartásának rendjéröl

${ }^{28}$ Éjszakai: 22-6 óra közötti.

${ }^{29}$ 20/2009. (VI. 29.) 3. §

${ }^{30}$ Kivételt képeznek a szabályozás alól a benzinkutak, valamint a szálláshelyek.

${ }^{31}$ Már korábban is született szabályozás: 2007-ben próbáltak először rendelettel beavatkozni, amikor megtiltották az éjjel-nappali boltoknak az alkoholárusítást 22 óra után.

${ }^{32}$ www. velvet.hu/sztori/2009/07/16/felszamoljak_a_belvarosban_a_szorakozast/ - 2010. május 1-jei letöltés

${ }^{33}$ www.hvg. hu -2010 . május 1-jei letöltés

${ }^{34}{ }_{\text {www.origo.hu/itthon/20090716-budapest-vi-kerulet-este-tizkor-bezaratna-a-szorakozohelyeket-az- }}$ onkormanyzat.html - 2010. május 1-jei letöltés

${ }^{35}$ A fövárosiak $90 \%$-a ellenezte a rendeletet.

${ }^{36}$ A rendelet 2500-3000 vendéglátóhelyet érint.

${ }^{37}$ www. ujkorcsoport. blog. hu -2010 . május 1-jei letöltés

38 www.jogiforum. hu -2010 . május 1-jei letöltés

${ }^{39}$ www.stop.hu/articles/article.php?id=525653 - 2010. május 1-jei letöltés

${ }^{40}$ Terézváros polgármester jelöltje. 
${ }^{41}$ Ez a megállapítás a Budapesti Kereskedelmi és Iparkamara Közleményében olvasható.

${ }^{42}$ www. vallalkozoinegyed. hu -2010 . május 1-jei letöltés

43 54/1993 (X.13.) AB határozat

${ }^{44}$ Alkotmány 70/B. $§(1)$ bekezdés 